\title{
PENEGAKAN HUKUM DI INDONESIA
}

\author{
Oleh:
}

Sanyoto

Fakultas Hukum Universitas Jenderal Soedirman Purwokerto

\begin{abstract}
The law enforcement shall do correctly and effectively to measure the succeed of the state, particularly in giving protection toward the citizen. The state realize that the law enforcement must related with the the five pillars of law instrument which are law builder, law enforcer, people consciousness, culture and infrastructure which supported. Expedient justify with increasing awareness of law society, so the consequence of building still as cut down action and not fait.
\end{abstract}

Kata kunci : penegakkan hukum, perlindungan masyarakat

\section{A. Pendahuluan}

Penegakan hukum ditujukan guna meningkatkan ketertiban dan kepastian hukum dalam masyarakat. Hal ini dilakukan antara lain dengan menertibkan fungsi, tugas dan wewenang lembaga-lembaga yang bertugas menegakkan hukum menurut proporsi ruang lingkup masing-masing, serta didasarkan atas sistem kerjasama yang baik dan mendukung tujuan yang hendak dicapai.

Tingkat perkembangan masyarakat tempat hukum diberlakukan mempengaruhi pola penegakan hukum, karena dalam masyarakat modern yang bersifat rasional dan memiliki tingkat spesialisasi dan differensiasi yang tinggi penggorganisasian penegak hukumnya juga semakin kompleks dan sangat birokratis.

Kajian secara sistematis terhadap penegakan hukum dan keadilan secara teoritis dinyatakan efektif apabila 5 pilar hukum berjalan baik yakni: instrument hukumnya,aparat penegak hukumnya, faktor warga masyarakatnya yang terkena lingkup peraturan hukum, faktor kebudayaan atau legal culture, factor sarana dan fasilitas yang dapat mendukung pelaksanaan hukum .

Hikmahanto Juwono menyatakan di Indonesia secara tradisional institusi hukum yang melakukan penegakan hukum adalah kepolisian, kejaksaan, badan peradilan dan advokat. Di luar institusi tersebut masih ada diantaranya , Direktorat Jenderal Bea Cukai, Direktorak
Jenderal Pajak, Direktorat Jenderal Imigrasi. Problem dalam penegakan hukum meliputi hal: ${ }^{1}$

1. Problem pembuatan peraturan perundangundangan.

2. Masyarakat pencari kemenangan bukan keadilan.

3. Uang mewarnai penegakan hukum.

4. Penegakan hukum sebagai komoditas politik, penegakan hukum yang diskriminatif dan ewuh pekewuh.

5. Lemahnya sumberdaya manusia.

6. Advokat tahu hukum versus advokat tahu koneksi.

7. Keterbatasan anggaran.

8. Penegakan hukum yang dipicu oleh media masa.

Problem tersebut di atas memerlukan pemecahan atau solusi, dan negara yang dalam hal ini diwakili pemerintah telah mengeluarkan kebijakan yang bertujuan memperbaiki kinerja institusi hukum, aparat penegak hukum dengan anggaran yang cukup memadai sedang outputnya terhadap perlindungan warganegara di harapkan dapat meningkatkan kepuasan dan sedapat mungkin mampu menjamin ketentraman dan kesejahteraan sosial bagi seluruh anggota masyarakat ${ }^{2}$.

\footnotetext{
Hikmahanto Juwono, 2006, Penegakan hokum dalam kajian Law and development :Problem dan fundamen bagi Solusi di Indonesia, Jakarta : Varia Peradilan No.244 hlm. 13

2 Bagir Manan,2007, Persepsi masyarakat mengenai Pengadilan dan Peradilan yang baik, Jakarta : Varia Peradilan No. $258 \mathrm{Mei}$, hlm. 5
} 
200 Jurnal Dinamika Hukum

Vol. 8 No. 3 September 2008

Berdasarkan uraian di atas, maka tulisan ini akan membahas tentang upaya-upaya yang telah dilakukan oleh negara dalam menyelesaikan problem penegakan hukum yang dihadapi sebagai wujud melindungi warga negara?

\section{B. Pembahasan}

1. Upaya meningkatkan peran penegak hukum untuk menumbuhkan kesadaran hukum anggota masyarakat.

Pelaksanaan hukum di dalam masyarakat selain tergantung pada kesadaran hukum masyarakat juga sangat banyak ditentukan oleh aparat penegak hukum, oleh karena sering terjadi beberapa peraturan hukum tidak dapat terlaksana dengan baik oleh karena ada beberapa oknum penegak hukum yang tidak melaksanakan suatu ketentuan hukum sebagai mana mestinya. Hal tersebut disebabkan pelaksanaan oleh penegak hukum itu sendiri yang tidak sesuai dan merupakan contoh buruk dan dapat menurunkan citra .Selain itu teladan baik dan integritas dan moralitas aparat penegak hukum mutlak harus baik, karena mereka sangat rentan dan terbuka peluang bagi praktik suap dan penyelahgunaan wewenang. Uang dapat mempengaruhi proses penyidikan, proses penuntutan dan putusan yang dijatuhkan.

Dalam struktur kenegaraan modern, maka tugas penegak hukum itu dijalankan oleh komponen yudikatif dan dilaksanakan oleh birokrasi, sehingga sering disebut juga birokrasi penegakan hukum. Eksekutif dengan birokrasinya merupakan bagian dari bagian dari mata rantai untuk mewujudkan rencana yang tercantum dalam (peraturan) hukum. Kebebasan peradilan merupakan essensilia daripada suatu negara hukum saat ini sudah terwujud dimana kekuasaan Kehakiman adalah merdeka yang bebas dari pengaruh unsur eksekutif, legislatif .serta kebebasan peradilan ikut menentukan kehidupan bernegara dan tegak tidaknya prinsip Rule of Law.

\section{Proses Penegakan Hukum di lingkungan Peradilan}

Peradilan sebagai salah satu institusi penegak hukum, oleh karenanya aktivitasnya tidak terlepas dari hukum yang telah dibuat dan disediakan oleh badan pembuat hukum itu. Dalam hal ini ada perbedaan peradilan dan pengadilan, peradilan menunjukan kepada proses mengadili, sedangkan pengadilan adalah merupakan salah satu lembaga dalam proses tersebut, lembaga-lembaga lain yang terlibat dalam proses mengadili adalah kepolisian, kejaksaan dan advokat.

Berjalannya proses peradilan tersebut berhubungan erat dengan substansi yang diadili yaitu berupa perkara perdata atau pidana, keterlibatan lembaga-lembaga dalam proses peradilan secara penuh hanya terjadi pada saat mengadili perkara pidana. Dalam perkembangannya terbentuklah beberapa badan peradilan dalam lingkup Peradilan Umum, Peradilan Agama, Peradilan Militer dan Peradilan Tata Usaha Negara, Pengadilan perpajakan dimana masing-masing mempunyai kewenangan untuk mengadili perkara sesuai dengan kewenangan masing-masing peradilan tersebut.

Menurut hemat penulis peranan lembaga peradilan dalam mewujudkan pengadilan yang mandiri, tidak dipengaruhi oleh pihak manapun, bersih dan profesional belum berfungsi sebagaimana yang diharapkan. Hal tersebut tidak hanya disebabkan oleh:

a. adanya intervensi dari pemerintah dan pengaruh dari pihak lain terhadap putusan pengadilan, tetapi juga karena kualitas profesionalisme, moral dan akhlak aparat penegak hukum yang masih rendah. Akibatnya kepercayaan masyarakat terhadap lembaga peradilan sebagai benteng terakhir untuk mendapatkan keadilan semakin menurun.

b. lemahnya penegakan hukum juga disebabkan oleh kinerja aparat penegak hukum lainnya seperti Hakim, Polisian, Jaksa, Advokat dan Penyidik Pegawai Negeri Sipil (PPNS) yang belum menunjukan sikap yang profesional dan integritas moral yang tinggi. Kondisi sarana dan prasarana hukum yang sangat diperlukan oleh aparat penegak hu- 
kum juga masih jauh dari memadai sehingga sangat mempengaruhi pelaksanaan penegakan hukum untuk berperan secara optimal dan sesuai dengan rasa keadilan di dalam masyarakat.

Sebagai upaya untuk meningkatkan pemberdayaan terhadap lembaga peradilan dan lembaga penegak hukum lainnya langkahlangkah yang perlu dilakukan yaitu:

a. Peningkatan kualitas dan kemampuan aparat penegak hukum yang lebih profesioanal, berintegritas, berkepribadian, dan bermoral tinggi.

b. Perlu dilakukan perbaikan-perbaikan sistem perekrutan dan promosi aparat penegak hukum, pendidikan dan pelatihan, serta mekanisme pengawasan yang lebih memberikan peran serta yang besar kepada masyarakat terhadap perilaku aparat penegak hukum.

c. Mengupayakan peningkatan kesejahteraan aparat penegak hukum yang sesuai dengan pemenuhan kebutuhan hidup. ${ }^{3}$

Krisis kepercayaan masyarakat terhadap hukum disebabkan antara lain karena masih banyaknya kasus korupsi, kolusi dan nepotisme (KKN) dan pelanggaran hak asasi manusia (HAM) yang belum tuntas penyelesaiannya secara hukum.

Dalam rangka memulihkan kembali kepercayaan masyarakat terhadap hukum, upaya yang harus dilakukan adalah :

a. Menginventarisasi dan menindak lanjuti secara hukum berbagai kasus KKN dan HAM.

b. Melakukan pemberdayaan terhadap aparat penegak hukum, khususnya aparat kepolisian, kejaksaan, pengadilan dan masyarakat.

c. Pemberian bantuan hukum kepada masyarakat yang tidak mampu.

Adanya kekerasan horizontal dan vertikal pada dasarnya disebabkan melemahnya penerapan nilai-nilai budaya dan kesadaran hukum masyarakat yang mengakibatkan rendahnya kepatuhan masyarakat terhadap hukum dan timbulnya berbagai tindakan penyalahgunaan wewenang. Demikian juga kurangnya sosialisasi

\footnotetext{
3 Bagir Manan, 2005, Penegakan Hukum yg berkeadilan, Jakarta : Varia Peradilan No. $245 \mathrm{hlm} 7$
}

peraturan perundang-undangan baik sebelum maupun sesudah diterapkan baik kepada masyarakat umum maupun kepada penyelenggara negara termasuk aparat penegak hukum. Upaya yang akan dilakukan adalah dengan meningkatkan pemahaman dan kesadaran hukum di semua lapisan masyarakat terhadap pentingnya hak-hak dan kewajiban masing-masing individu yang pada akhirnya diharapkan akan membentuk budaya hukum yang baik.

Penegakan hukum sangat dipengaruhi oleh keadaan dan interaksi sosial yang terjadi dalam masyarakat, dapat dicantumkan dalam masyarakat yang memelihara atau mengembangkan sistem hak-hak berdasarkan atas status, atau suatu masyarakat dengan perbedaan yang tajam antara " the have " dan "the have not ", atau suatu masyarakat yang berada dalam lingkungan kekuasaann otoriter, akan menempatkan sistem penegakan hukum yang berbeda dengan masyarakat yang terbuka dan egaliter. Dengan kata lain penegakan hukum yang benar dan adil ditentukan oleh kehendak dan partisipasi anggota masyarakat, bukan semata-mata keinginan pelaku penegak hukum.

\section{Upaya Pemberdayaan Lembaga Peradilan dan Lembaga Penegak Hukum Lainnya.}

Pemberdayaan peradilan dan lembaga penegak hukum bertujuan untuk meningkatkan kembali kepercayaan masyarakat terhadap peran dan citra lembaga peradilan dan lembaga penegak hukum seperti; Pengadilan, Kejaksaan, Kepolisian dan Penyidik Pegawai Negeri Sipil Lainnya (PPNS) sebagai bagian dari upaya mewujudkan upaya supremasi hukum dengan dukungan hakim dan aparat penegak hukum lainnya yang profesional, berintegritas dan bermoral tinggi.

Dalam rangka mewujudkan Penegakan Hukum dilingkungan peradilan demi terciptanya lembaga peradilan yang bebas dari pengaruh penguasa maupun pihak lain dengan tetap mempertahankan prinsip cepat, sederhana dan biaya ringan hal-hal yang perlu dilakukan adalah: 
a. Meningkatkan pengawasan dalam proses peradilan secara transparan untuk memudahkan partisipasi masyarakat dalam rangka pengawasan dan pembenahan terhadap sistem manajemen dan administrasi peradilan secara terpadu.

b. Menyususn sistem rekruitmen dan promosi yang lebih ketat dan pengawasan terhadap proses rekruitmen dan promosi dengan memegang asas kompetensi, transparansi, dan partisipasi baik bagi hakim maupun bagi aparat penegak hukum lainnya.

c. Meningkatkan kesejahteraan hakim dan aparat penegak hukum lainnya seperti jaksa, Polisi dan PNS melalui peningkatan gaji dan tunjangan-tunjangan lainnya sampai dengan tingkat pemenuhan kebutuhan hidup yang disesuaikan dengan tugas, wewenang dan tanggung jawab kerja yang dibebankan.

d. Menunjang terciptanya sistem peradilan pidana yang terpadu melalui sinkronisasi peraturan perundang-undangan yang mengatur tugas dan wewenang hakim dan aparat penegak hukum lainnya.

e. Meningkatkan peran Advokat dan Notaris melalui optimalisasi standar kode etik di lingkungan masing-masing.

f. Menyempurnakan kurikulum dibidang pendidikan hukum guna menghasilkan aparatur hukum yang profesional, berintegrasi dan bermoral tinggi.

g. Meningkatkan kualitas hakim dalam melakukan penemuan hukum baru melalui putusanputusan pengadilan (yurisprudensi) yang digunakan sebagai dasar pertimbangan hukum, yang dapat digunakan oleh aparat penegak hukum dilingkungan peradilan.

h. Meningkatkan pembinaan terhadap integritas moral, sikap perilaku dan pemberdayaan kemampuan dan kerterampilan aparat penegak hukum.

i. Mengembangkan mekanisme penyelesaian sengketa alternatif di luar pengadilan atau Alternative Dispute Resolution (ADR) dan dengan memperbaiki upaya perdamaian di Pengadilan. j. Meningkatkan mekanisme pertanggungjawaban lembaga pengadilan kepada publik, kemudahan akses masyarakat untuk memperoleh putusan pengadilan dan publikasi mengenai ada tidaknya perbedaan pendapat di antara majelis hakim terhadap setiap pengambilan keputusan.

k. Melakukan pembinaan pemasyarakatan baik pembinaan di dalam maupun di luar lembaga pemasyarakatan, agar bekas warga binaan dapat kembali hidup normal di dalam masyarakat.

Negara Indonesia sebagai negara hukum tentang adanya kebebasan peradilan telah di jamin sebagimana tersebut dalam Undangundang Dasar 1945 hasil Amandemen dan Undang-undang Nomor 4 Tahun 2004 tentang Kekuasaan Kehakiman. Kekuasaan Kehakiman menurut UUD 1945 merupakan kekuasaan yang merdeka yang dilakukan oleh Mahkamah Agung dan Badan Peradilan dibawahnya, dan oleh sebuah Mahkamah Konstitusi untuk menyelenggarakan peradilan guna menegakan hukum dan keadilan. Perubahan UUD Dasar RI 1945 telah membawa perubahan penting terhadap penyelenggaraan kekuasaan kehakiman Undangundang Nomor 14 Tahun 1970 tentang Ketentuan-ketentuan Pokok Kekuasaan Kehakiman telah diubah dengan UU Nomor 35 Tahun 1999 dan kemudian dirubah lagi menjadi UU Nomor 4 Tahun 2006

Dalam Pasal 1 Undang-undang Kekuasaan Kehakiman Nomor 4 Tahun 2004 menyebutkan bahwa:

"Kekuasaan kehakiman adalah kekuasaan negara yang merdeka untuk menyelenggarakan peradilan guna menegakkan hukum dan keadilan berdasarkan Pancasila, demi terselenggaranya Negara Hukum Republik Indonesia".

Kekuasaan kehakiman yang merdeka dalam ketentuan tersebut di atas adalah bahwa kekuasaan kehakiman bebas dari segala campur tangan pihak eksternal yudisial kecuali dalam hal sebagaimana diatur dalam UUD Negara RI Tahun 1945. Kebebasan dalam melaksanakan wewenang yudisial bersifat tidak mutlak karena 
tugas hakim adalah untuk menegakkan hukum dan keadilan berdasarkan Pancasila sehingga putusannya mencerminkan keadilan rakyat Indonesia.

Aparat penegak hukum yang turut membantu dalam penyelenggaraan pelaksanaan peradilan untuk menciptakan kepastian hukum selain lembaga kehakiman meliputi:

a. Kejaksaan sebagaimana diatur dalam Undang-undang Nomor. 16 Tahun 2005 tentang Kejaksaan Republik Indonesia.

Kejaksaan Republik Indonesia adalah lembaga pemerintah yang melaksanakan kekuasaan negera di bidang penuntutan serta kewenangan lain berdasarkan Undangundang yang dilaksanakan secara merdeka.

Kejaksaan mempunyai tugas:

1) melakukan penuntutan;

2) melaksakan penetapan hakim dan putusan pengadilan yang telah memperoleh kekuatan hukum tetap.

3) Melakukan pengawasan terhadap pelaksanaan putusan pidana bersyarat, putusan pidana pengawasan dan keputusan lepas bersyarat.

4) Melakukan penyelidikan terhadap tindak pidana tertentu berdasarkan Undang-undang

5) Melengkapi berkas perkara tertentu, melakukan pemeriksaan tambahan sebelum dilimpahkan kepengadilan.

6) Di bidang perdata dan tata usaha negara kejaksaan dengan kuasa khusus dapat bertindak baik di dalam maupun diluar pengadilan untuk dan atau atas nama pemerintah.

7) Di bidang ketertiban dan ketentraman melaksanakan kegiatan peningkatan kesadaran hukum masyarakat, pengamanan kebijakan penegak hukum, pengawasan peredaran barang cetakan, pengawasan kepercayaan yang dapat membahayakan negara, pencegah penyelahgunaan dan penodaan negara.

b. Kepolisian sebagaimana diatur dalam Undang-undang Nomor 2 tahun 2002 tentang Kepolisian Negara Republik Indonesia.
Kepolisian Negara RI mempunyai tugas dan fungsi untuk memelihara keamanan dan ketertiban masyarakat, penegakan hukum, perlindungan, pengayoman dan pelanan kepada masyarakat.

Dalam rangka peningkatan upaya pelaksanaan dan penegakan hukum baik bagi masyarakat maupun aparat penegak hukum itu sendiri, maka pemerintah Negara RI telah melakukan pembaharuan terhadap beberapa peraturan untuk memperbaiki sistem hukum yang ada demi tercapainya masyarakat yang adil dan tentram, dengan adanya perbaikan peraturan bagi para aparat penegak hukum maka masing-masing pihak diharapkan dapat melaksanakan tugas, fungsi dan wewenangnya masing-masing secara bertanggung jawab, pelaksanaan tersebut tidak lepas dari pengawasan pemerintah dan masyarakat.

Pembicaraan Penegakan hukum dalam kenyataan sehari-hari tampak bahwa hubungan antara penegakan hukum dan struktur masyarakat memberikan pengaruh yang kuat terhadap cara-cara penegakan hukum suatu Negara. ${ }^{4}$ Indonesia sebagai Negara modern tampak dari ciri-cirinya sebagai berikut :

a. Adanya UUD dalam bentuk yang tertulis.

b. Hukum itu berlaku untuk wilayah Negara.

c. Hukum merupakan sarana yang dipakai secara sadar untuk mewujudkan keputusankeputusan politik masyarakatnya.

d. Menurut Max Weber cara penegakan hukum pada suatu masa berbeda dengan masa yang sebelumnya yang tentunya tidak terlepas dari dominasi yang disebabkan karena keadaan masyarakatnya yang berbeda, dimana tatanan kehidupan masyarakatnya menurut Hart dalam Satjipto Rahardjo didasarkan Secondary Rules Obligation di mana masyarakatnya mempunyai kehidupan yang terbuka, luas, dan komplek seperti saat ini maka terdapat diferensiasi dan institusionalisasi pekerjaan hukum berupa :

1) Rules of Recognition.

2) Rules of Change

\footnotetext{
4 Satjipto Rahardjo, 1983, Masalah Penegakan Hukum, Bandung : Sinar baru, hlm. 8
} 
204 Jurnal Dinamika Hukum

Vol. 8 No. 3 September 2008

3) Rules of adjudication.

Salah satu yang menonjol yang dirasakan di Indonesia saat ini adalah sifat birokratisnya penegakan hukum yang sesuai dengan kewenangan masing-masing institusi atau lembaga hukum yang bertugas menegakkan hukum sesuai dengan kewenangan yang telah diberikan undang-undang

\section{Penutup}

Berdasarkan uraian tersebut di atas dapat disimpulkan upaya untuk mencapai ketertiban dan keadilan dalam penegakan hukum telah ada perubahan dan perbaikan dari sistem peradilan itu sendiri, serta upaya meningkatkan sumber daya manasia dan pemberdayaan lembaga peradilan dan lembaga penegak hukum lainnya (Kepolisian dan Kejaksaan) serta adanya partisipasi masyarakat demi mewujudkan hukum yang berkeadilan dan mengayomi masyarakat.

\section{Daftar Pustaka}

Juwono, Hikmahanto. 2006. Penegakan Hukum Dalam kajian Law and Development: Problem dan Fundamen bagi Solusi di Indonesia. Varia Peradilan No. 244, Jakarta;

Manan, Bagir. 2005. Penegakan Hukum Yang Berkeadilan. Varia Peradilan No.241, Jakarta;

........... 2007. Persepsi Masyarakat Mengenai Peradilan yang Baik. Varia Peradilan No.258, Jakarta;

Rahardjo, Satjipto. 1983. Masalah Penegakan Hukum Suatu Tinjauan Sosiologis. Bandung: Sinar Baru;

Soekanto, Soerjono, 1983, Faktor-faktor yang Mempengaruhi Penegakan Hukum. Jakarta: Rajawali Pers;

Sutiyoso, Bambang. 2004. Aktualita Hukum Dalam Era Reformasi. Jakarta: RajawaliPers.

\section{Perundang - undangan}

Undang-undang Nomor 25 Tahun 2000 tentang Program Perencanaan Pembangunan Nasional

Undang Undang Nomor 2 Tahun 2002 tantang Kepolisian Negara Republik Indonesia

Undang - Undang Nomor 4 Tahun 2004 Tahun 2004 tentang Kekuasaan Kehakiman

Undang-undang Nomor 16 Tahun 2004 tentang Kejaksaan Republik Indonesia 